SILVA, AJ; OLIVEIRA, GHF; PASTORIZA, RJG; MARANHÃO, EHA; PEDROSA, EMR; MARANHÃO, SRVL; BOITEUX, LS; PINHEIRO, JB; CARVALHO FILHO, JLS. 2019. Search for sources of resistance to Meloidogyne enterolobii in commercial and wild tomatoes. Horticultura Brasileira 37: 188-198. DOI - http://dx.doi.org/10.1590/S0102-053620190209

\title{
Search for sources of resistance to Meloidogyne enterolobii in commercial and wild tomatoes
}

\author{
Alysson J da Silva ${ }^{1} \mathbb{D}$; Gustavo HF de Oliveira ${ }^{2} \mathbb{D}$; Rhuan JG Pastoriza ${ }^{3} \mathbb{D}$; Eduardo HA Maranhão \\ (in memoriam) ${ }^{4}$; Elvira MR Pedrosa ${ }^{3} \mathbb{D}$; Sandra RVL Maranhão ${ }^{3} \mathbb{D}$; Leonardo S Boiteux ${ }^{5} \mathbb{D}$; Jadir B \\ Pinheiro ${ }^{5} \mathbb{D}$; José Luiz S de Carvalho Filho ${ }^{3} \mathbb{D}$
}

${ }^{1}$ NovAmérica Agrícola, Tarumã-SP, Brazil; ${ }^{2}$ Universidade Federal de Sergipe, Campus do Sertão (UFS), Nossa Senhora da Glória-SE, Brazil; ${ }^{3}$ Universidade Federal Rural de Pernambuco (UFRPE), Recife-PE, Brazil; ${ }^{4}$ Instituto Agronômico de Pernambuco (IPA), Vitória de Santo Antão-PE, Brazil; ${ }^{5}$ Embrapa Hortaliças, Brasília-DF, Brazil; jalles10@gmail.com (corresponding author)

\begin{abstract}
Meloidogyne enterolobii (=M. mayaguensis) is an emerging plant pathogen capable of inducing root galls and yield reduction in a wide range of host species. This pathogen has also been reported as a global threat for tomato (Solanum lycopersicum) crop production mainly due to its ability to overcome the resistance meditated by the Mi-1 gene. Despite the potential importance of this nematode, sources of resistance to $M$. enterolobii are not yet available for breeding purposes. The main objective of the present work was to evaluate a large Solanum (section Lycopersicon) germplasm (comprising nine species and one botanic variety) aiming to identify useful sources of resistance to $M$. enterolobii. In the first screening assay, 101 accessions and the susceptible standard S. lycopersicum 'Santa Cruz' were inoculated and evaluated under controlled conditions. The phenotypic criteria used for evaluation were the number of root galls, gall index, number of eggs, and the reproduction factor. Plants of the 20 selected accessions were cultivated in $0.4 \mathrm{~L}$ pots filled with sterile soil. Inoculation procedures were identical to the first assay, but with higher inoculum pressure (3,300 eggs per plant). Three accessions with superior tolerance levels to $M$. enterolobii were identified viz. S. lycopersicum 'Yoshimatsu', S. lycopersicum 'CNPH 1246' and S. Pimpinellifolium CGO 7650 (= CNPH 1195). These accessions were re-evaluated against a distinct $M$. enterolobii population as well as against two other root-knot nematode species (M. javanica and one $M$. incognita race 1). Under higher inoculum pressure, 'Yoshimatsu' was found to be resistant to $M$. javanica and $M$. incognita race 1, but susceptible to $M$. enterolobii from guava. The other two sources displayed susceptibility to all three nematodes. Additional germplasm screening is needed since no source of stable genetic resistance to $M$. enterolobii was found so far.
\end{abstract}

Keywords: Solanum spp., germplasm, screening, root-knot nematode.

\section{RESUMO}

Busca por fontes de resistência a Meloidogyne enterolobii em tomateiros comerciais e selvagens

Meloidogyne enterolobii (=M. mayaguensis) é um patógeno de plantas capaz de induzir galhas e reduzir produtividade de uma vasta gama de espécies hospedeiras. Este patógeno tem sido também reportado como ameaça global para a cultura do tomateiro (Solanum lycopersicum), principalmente, por causa da sua habilidade de suplantar a resistência a algumas espécies de Meloidogyne mediada pelo gene $M i-1$. Apesar da importância potencial deste nematoide, fontes de resistência a $M$. enterolobii ainda não estão disponíveis para fins de melhoramento. O principal objetivo do presente trabalho foi avaliar um amplo germoplasma de Solanum (seção Lycopersicon) composto por nove espécies e uma variedade botânica, objetivando identificar fontes de resistência a M. enterolobii. No primeiro ensaio, 101 acessos e a cultivar Santa Cruz, empregada como padrão de suscetibilidade, foram inoculados e avaliados sob condição controlada. As variáveis foram o índice de galhas, número de galhas e de ovos nas raízes e o fator de reprodução. Vinte acessos promissores quanto à reação de resistência a $M$. enterolobii, no primeiro ensaio, foram selecionados e testados no ensaio seguinte. Os acessos $S$. lycopersicum 'Yoshimatsu', S. lycopersicum 'CNPH 1246' e S. Pimpinellifolium CGO 7650 (= CNPH 1195) foram identificados com melhor comportamento de resistência a $M$. enterolobii. Estes acessos foram reavaliados contra uma população distinta de $M$. enterolobii e também contra $M$. javanica e M. incognita raça 1. Sob maior pressão de inóculo, 'Yoshimatsu' foi resistente a $M$. javanica e a $M$. incognita raça 1, mas, suscetível a $M$. enterolobii. Os outros dois acessos foram suscetíveis aos três nematoides. Germoplasmas adicionais devem ser avaliados uma vez que fontes de resistência a $M$. enterolobii ainda não foram encontradas.

Palavras-chave: Solanum spp., prospecção, nematoide-das-galhas, controle genético, melhoramento.

\section{Received on July 27, 2018; accepted on March 13, 2019}

$F^{n-10}$ ruit quality and yield of cultivated tomato (Solanum lycopersicum) are severely affected by nematode species, especially in tropical and subtropical areas of the world (Moens et al., 2009). Meloidogyne species are very difficult to control via chemical and cultural methods, being a very serious problem when a susceptible tomato crop is established in already infested soils (Elling, 2013) and, or under protected crop system.
Meloidogyne enterolobii is a new invasive root-knot nematode species with an extremely wide host range, which includes the original host pacara earpod tree (Enterolobium contortisiliquum) as well as guava (Psidium guajava), 
acerola (Malpighia glabra), weed and ornamental plants, tomato (Solanum lycopersicum) and many vegetable crops (Yang \& Eisenback, 1983; Carneiro et al., 2001). An earlier confirmation of $M$. enterolobii as a new species was delayed since it was much likely misidentified as M. incognita (Elling, 2013).

Symptoms of M. enterolobii in many host plants include overall chlorosis and stunting associated with the presence of large root galls and root necrosis (Elling, 2013). This nematode has been already reported occurring in Asia (China and Vietnam), Europe (France and Switzerland); Central America (Puerto Rico), South America (Brazil) and North America (Florida) as well as in the African continent (Elling, 2013). In Brazil, M. enterolobii (initially described as M. mayaguensis) was first reported causing severe yield losses in guava orchards in Pernambuco and Bahia States (Carneiro et al., 2001). After this initial report, $M$. enterolobii was reported in virtually all geographic areas of the country (Siqueira et al., 2009), affecting also tomatoes and bell peppers (Capsicum annuum) under protected crop systems in Southeast Brazil.

So far, the employment of cultivars and rootstocks with genetic resistance has been the major strategy to control the damages caused by root-knot nematodes in tomato. Sources of resistance to Meloidogyne species in the genus Solanum (section Lycopersicon) were first identified in $S$. peruvianum accessions and a single, dominant gene (Mi-1) was successfully introgressed into S. lycopersicum via interspecific crosses and embryo rescue techniques. The Mi-1 gene confers large-spectrum resistance, being effective against isolates and races of three root-knot nematode species (M. incognita, M. javanica, and $M$. arenaria). The resistance of the Mi-1 gene was mapped to the top region of the chromosome 6 and it was already cloned and characterized. Introgression of the Mi-1 gene into commercial tomato cultivars was a very important breeding achievement, avoiding yield and quality losses caused mainly by mixed infections of $M$. incognita and M.javanica, a common feature observed in many producing areas of the world. However, this gene is not effective to M. hapla and also against isolates of $M$. brasiliensis (Charchar et al., 2010). In fact, $M$. enterolobii has been reported as a potential threat for tomato crop in tropical and subtropical areas, especially due to its ability to overcome the resistance meditated by the $M i-1$ gene (Yang \& Eisenback, 1983). In tomato cultivars and rootstocks (with and without the $M i-1$ gene), $M$. enterolobii is able to induce stunting and extensive root galling, which might result in drastic yield and quality losses (Pinheiro et al., 2009).

In addition to the $M i-1$, new resistance genes/alleles to Meloidogyne species (named as Mi-2 up to Mi-9) have been reported in Solanum accessions and some of these genetic factors have been also located in the chromosome 6 as well as in the chromosome 12 (Jablonska et al., 2007). Some of these genes as well as other not yet fully characterized loci can confer resistance to $M$. hapla and, or can be effective under high temperature or against some resistancebreaking M. incognita isolates (Veremis \& Roberts, 1996). However, there is so far no information about the reaction of these new sources of resistance to $M$. enterolobii. In addition, there is yet an unexplored genetic variability in Solanum (lycopersicon) for $M$. enterolobii resistance and this pathogen opens the opportunity to discover alternative resistance genes/alleles in this rich germplasm (Pinheiro et al., 2009; Melo et al., 2011).

Even though considered yet as a potential threat to the tomato crop, preemptive breeding to $M$. enterolobii resistance will be an important component aiming to minimize potential worldwide damages. In this context, the identification and incorporation into elite germplasm of broad spectrum resistance factors to Meloidogyne species (including M. enterolobii) is highly desirable, especially in tropical and subtropical regions where tomato is cultivated under high nematode inoculum pressure. We aimed to search for sources of stable genetic resistance to M. enterolobii exploring a large Solanum (section Lycopersicon) germplasm collection, comprising accessions of the cultivated and wild species.

\section{MATERIAL AND METHODS}

\section{Experimental location and conditions}

The experiments were carried out in a greenhouse system belonging to the Laboratory of Plant Nematology, Agronomy Department, Universidade Federal Rural de Pernambuco (UFRPE), Recife, Pernambuco State, Brazil ( $8^{\circ} 01^{\prime} 02^{\prime}$ 'S, $\left.34^{\circ} 56^{\prime} 41^{\prime \prime} \mathrm{W}\right)$. The Solanum (section Lycopersicon) accessions evaluated in the present work are part of the germplasm collection maintained at Embrapa Hortaliças located in Brasilia-DF, Brazil. This germplasm collection comprised accessions classified into nine species and one botanic variety viz. S. lycopersicum, S. lycopersicum var. cerasiforme, S. pimpinellifolium, $S$. peruvianum, S. chilense, S. habrochaites, S. pennellii, S. corneliomulleri, S. neorickii, and S. chmielewski (Full accession list in supplementary table).

\section{First screening assay: Meloidogyne enterolobii population and inoculum preparation}

The M. enterolobii population employed in the present work was initially obtained from infected guava plants and then cultured on S. lycopersicum 'Santa Cruz' under greenhouse conditions (UFRPE). Eggs of $M$. enterolobii employed as inoculum in all assays were collected according to the technique of Hussey \& Barker (1973) with minor modifications introduced by Boneti \& Ferraz (1981). In short, roots with galls and egg masses were washed free of soil and cut into 2-cm pieces and dipped into a diluted sodium hypochlorite solution. Root segments were then triturated for 30 $\mathrm{s}$ at $200 \mathrm{rpm}$ in a blender. Eggs were separated from plant and soil debris by pouring the suspension through a series of sieves and collecting them on a 38 $\mu \mathrm{m}$-pore mesh.

First screening assay: Evaluation 
of 101 Solanum (Lycopersicum) accessions to one $M$. enterolobii population

One hundred and one Solanum (section Lycopersicon) accessions were evaluated in the first experiment. Seedlings were produced in polystyrene trays (68x34 cm / 128 cells / 40 mL/cell) filled with commercial solid substrate $\left(\right.$ Basaplant $\left.t^{\circledR}\right)$. The experiment was conducted only in polystyrene trays. The assay was set up in a randomized block design with two replications (two lines with eight plants of each tomato genotype were evaluated). Only a single plant was allowed to grow in each tray cell. One tray line (with eight plants each) of the susceptible tomato 'Santa Cruz' was included as internal control in each tray in order to monitor the inoculum viability. The trays were kept in a greenhouse free of insect infestation with daily irrigation and without pesticide applications. Temperature range during the assay was 21.6 to $31.7^{\circ} \mathrm{C}$ and relative air humidity range was 54.8 to $91.3 \%$. Substrate infestation was carried out 20 days after sowing with an egg suspension (adjusted to $710 \mathrm{M}$. enterolobii eggs/ $\mathrm{mL}$ ). Inoculum was placed at crown area around the stem of each plant (1 $\mathrm{mL}$ of the inoculum suspension/plant) with the aid of a disposable syringe. Presence of root galls in the susceptible control was checked weekly. The most adequate time to carry out the germplasm evaluation was established when profuse gall formation was observed (around 45 days after inoculation) in the susceptible control.

The phenotypic criteria used for evaluation of each individual plant were number of galls, gall index, number of eggs, and the reproduction factor. The number of galls was visually estimated in roots immersed in water in order to remove the substrate. The gall index was assessed using the scale of Carvalho Filho et al. (2011) [1= few visible $(<10$ galls) and small $(<1 \mathrm{~mm})$ galls; $2=$ few visible galls, but with intermediate size ( 1 to $3 \mathrm{~mm}$ ); $3=$ intermediate number of visible galls (10 to 30 galls), standard size, with some large galls ( $>3 \mathrm{~mm}) ; 4=$ many visible ( $>30$ galls) predominantly large $(>3 \mathrm{~mm})$ galls, with few of intermediate size, some galls already coalescing; $5=$ high number $(>30$ galls $)$ of large, conspicuous galls, many of them already coalescing]. The levels of resistance/susceptibility were grouped according to Boiteux \& Charchar (1996) (grades between 1.0 and 1.6 were classified as highly resistant; from 1.7 to 2.3 = resistant; from 2.4 to $3.0=$ intermediate; from 3.1 to 4.0 = susceptible; from 4.1 to $5.0=$ highly susceptible). The number of nematode eggs in the root system of each accession was determined by counting the eggs under a dissecting stereomicroscope after extraction employing the technique described by Hussey \& Barker (1973) with modifications introduced by Boneti \& Ferraz (1981) and then counted using a microscope. The reproduction factor (RF) was calculated as the number of eggs observed in each inoculated plant [ = final nematode population (FP)] divided by number of eggs used for inoculation of each plant [= initial nematode population (IP)] (Oostenbrink, 1966).

Second screening assay: Reevaluation of 20 selected Solanum (Lycopersicum) accessions against $M$. enterolobii

Twenty accessions with the lowest values for gall index, gall number, number of eggs, and reproduction factor in the first assay were selected for a subsequent assay. The cultivars Santa Cruz and Yoshimatsu (S. lycopersicum) (previously identified as a promising resistant material) were included in this second assay as susceptible and resistant standards, respectively. The second assay was set up in a randomized block design with three replications. The experimental plots were composed by three $0.4-\mathrm{L}$ plastic pots (one plant/pot) filled with sterile soil. The cultivation in large pots was carried out in order to allow a better root development when compared to the first assay (conducted in polystyrene trays). Temperature ranged between 23.6 and $33.6^{\circ} \mathrm{C}$ and relative air humidity range was 55.8 to $92.8 \%$. Substrate infestation was carried out 20 days after sowing (straight in the soil) with a nematode egg suspension (adjusted to 1,100 eggs/mL). Inoculum was placed at the crown area around the stem of each plant $(3 \mathrm{~mL}$ of the inoculum suspension per plant $=3,300$ eggs per plant) using a disposable syringe. Presence of root galls in the susceptible control was checked weekly. The most adequate time to carry out the germplasm evaluation was established 45 days after inoculation (identical to that of the first assay). Three traits (gall number, number of eggs, and reproduction factor) were evaluated for each plant essentially as described in the first assay.

\section{Statistical analyses of the first and second assays}

The statistical model for the first assay was a randomized complete block design $y_{i j}=\mu+\pi_{i}+\beta_{j}+\varepsilon_{i j}$, where $\mathrm{y}_{\mathrm{ij}}$ is $\mathrm{ij}^{\text {th }}$ observation, $\mu$ is an overall mean, $\pi_{i}$ is the effect of $i^{\text {th }}$ treatment, $\beta_{\mathrm{j}}$ is the block effect $\mathrm{j}^{\text {th }}$, and $\varepsilon_{\mathrm{ij}}$ is the usual NID $\left(0, \sigma^{2}\right)$ random error term. Exploratory data analysis for the two assays were carried out in order to check the assumptions underlying analysis of variance and homoscedasticity of the data set using the Shapiro-Wilk and Bartlett tests (SAS, 2009). In both assays a departure was detected from the normality for all variables observed (gall number, egg number and reproduction index). For this reason, we used an adaptation of the Box-Cox transformation family as described in Yamamura (1999). In the first assay the variables were transformed to $\ln (\mathrm{y})$ and in the second assay the number of galls was transformed to $\ln (\mathrm{y})$, number of eggs was transformed to $\sqrt{\mathrm{y}+0.5}$, and reproduction factor was transformed to $\ln (\sqrt{\mathrm{y}+0.5})$. The Scott-Knott test was carried out to assess significant differences among accessions. The tests for normality, homoscedasticity and the Box-Cox transformations were carried out with the software package SAS 9.2 (SAS, 2009). The Scott-Knott test was carried out using the software package SISVAR 5.3 (Ferreira, 2011).

Third assay: Evaluation of the three most promising Solanum (Lycopersicum) accessions to a distinct $M$. enterolobii population and to $M$. javanica and $M$. incognita race 1 populations 
This experiment was carried out from May to September 2014 under greenhouse conditions at Embrapa Hortaliças $\left(15^{\circ} 56^{\prime} 00^{\prime \prime} \mathrm{S}, 48^{\circ} 06^{\prime} 00^{\prime \prime} \mathrm{W}\right.$, $25^{\circ} \mathrm{C}$ ). Three tomato accessions (Yoshimatsu, CNPH 1195 and $\mathrm{CNPH}$ 1246) identified in previous assays as being the most promising resistance sources to $M$. enterolobii were reevaluated for their reaction to a distinct M. enterolobii population (aiming to confirm their reaction) as well as to one $M$. javanica population and one $M$. incognita race 1 population. The susceptible and resistant controls were tomato cultivars Rutgers and Nemadoro, respectively. Females of $M$. javanica and $M$. incognita race 1 populations were collected from individually infected tomato roots in the experimental area of Embrapa Hortaliças. Meloidogyne incognita race was characterized after inoculation of a set of race-differential host species (Taylor \& Sasser, 1978). M. enterolobii was obtained from infected guava trees in Palmas, Tocantins State, Brazil (Charchar et al., 2010). All populations used as inoculum sources were kept under greenhouse conditions. Analyses of the perineal pattern morphology confirmed the species identification of each population. Species-specific esterase patterns (Carneiro \& Almeida, 2001) also confirmed the taxonomic status of each population.

\section{Inoculum production}

Nematode populations were multiplied in tomato cv. Rutgers. Seedlings (ten days after germination) obtained in styrofoam trays were transplanted to pots containing 3 L sterile Plantmax ${ }^{\circledR}$ substrate. The inoculation of the seedlings' roots was performed eight days after transplanting using a suspension of 4,000 eggs and second stage juveniles (J2) of each species separately. Inoculum suspension $(5 \mathrm{~mL})$ was distributed around the crown of each plant. Around 60 days after inoculation, $\mathrm{J} 2$ and eggs were extracted from the root systems following the methodology described by Hussey \& Barker (1973) and modified by Boneti \& Ferraz (1981).

Evaluation of the tomato accessions
Fourteen-day old seedlings of the three tomato accessions and the two standard cultivars obtained in styrofoam trays were transplanted to pots containing 3 L sterile Plantmax ${ }^{\circledR}$ substrate. The inoculation of the seedlings' roots was performed eight days after transplanting using a suspension of 4,000 eggs and $\mathrm{J} 2$ of each species separately. The experiment was conducted in a completely randomized factorial design $5 \times 3$ (five tomato genotypes $x$ three nematode species), with six replicates (one plant per pot). Eightythree days after inoculation, plants were evaluated for egg mass index, gall index, number of eggs per gram of root, and reproduction factor. For egg-mass index (IMO), the plants were collected, root systems washed under running water, and the roots colored by immersion in a solution of phloxine $\mathrm{B}(0.5 \mathrm{~g} / \mathrm{L}$ water) during 15 minutes. Then, the egg mass number was counted, using a stereoscopic microscope, throughout the plant's root system/replication (Taylor \& Sasser, 1978). The IMO in the roots was obtained according to Taylor \& Sasser (1978) using a scale of notes $(0=$ roots without egg mass; $1=$ presence of 1 to 2 egg masses; $2=$ presence of 3 to 10 egg masses; $3=$ presence of 11 to 30 egg masses; $4=$ presence of 31 to 100 egg masses and $5=$ more than 100 egg masses). The traits gall number, number of eggs, and the reproduction factor were evaluated for each plant essentially as described in the first assay.

\section{RESULTS AND DISCUSSION}

\section{First screening assay employing} 101 Solanum (Lycopersicon) accessions

For the criterion number of galls, 34 accessions displayed values significantly lower than that of the susceptible standard tomato "Santa Cruz' (Table 1). Twelve from this group also showed significant lower gall index values in comparison to tomato 'Santa Cruz'. Two of these accessions [S. habrochaites 'PI-247087' (= CNPH $1288)$ and S. habrochaites 'PI-126449' (= CNPH 1290)] were classified as highly resistant. Ten accessions were classified as resistant viz. S. peruvianum
'PI 126408' (= CNPH 0102), $S$. lycopersicum 'Venus' (= CNPH 0181), S. lycopersicum Cannary Row $(=\mathrm{CNPH}$ 0969), S. chmielewski (CNPH 1022), S. lycopersicum 'Hawaii-7996' (= CNPH 1048), S. lycopersicum (CNPH 1226), S. chilense 'LA 1963' (= CNPH 1238), S. lycopersicum 'PI 126428' (= CNPH 1260), S. pennellii 'LA 416' (= CNPH 409) and S. peruvianum 'LA 1616' (= CNPH 798). The remaining accessions presented high number of galls, similar to that observed in the susceptible standard (Table 1). The gall number and gall index are practical and non-destructive methods to evaluate Meloidogyne-host plant interactions. In relation to gall number, the ideal phenotypic reaction from the resistance breeding standpoint is an immunity-like response characterized by the complete absence of root galls and giant cells. The presence of giant cells in the vascular cylinder induced by nematode attack is the main factor restricting water flow and proper nutrient uptake in susceptible plants (Westerich et al., 2011).

In the first assay, the gall index was efficient to discriminate the accessions, which allows the allocation of the genetic materials in a wide range of responses, varying from highly resistant to highly susceptible (Table 1). Twenty-three accessions displayed mean values for gall index significantly lower than that of the susceptible standard (the tomato cultivar Santa Cruz). In this assay, the accessions were classified according to the gall index into the following reaction groups: two accessions were classified as highly resistant; 21 as resistant; 39 as moderately resistant; 35 as susceptible and four as highly susceptible. Eleven accessions evaluated in our assay were also evaluated in a previous screening assay to $M$. enterolobii reaction (Pinheiro et al., 2009). The accessions S. habrochaites 'PI 247087' (= CNPH 1288) and S. habrochaites 'PI 126449' (= CNPH 1290) were also classified as highly resistant displaying the lowest gall index values (Pinheiro et al., 2009). Likewise, the accession $S$. lycopersicum 'CNPH 0969' classified as resistant in our assay was also reported as resistant.

In our first assay, 46 accessions had 
Table 1. Gall index; number of galls; number of eggs; and reproduction factor values of 101 Solanum (section Lycopersicon) accessions and the susceptible standard cultivar S. lycopersicum 'Santa Cruz' evaluation (45 days after inoculation) after Meloidogyne enterolobii inoculation. Recife, UFRPE, 2012.

\begin{tabular}{|c|c|c|c|c|c|c|c|}
\hline Accession & $\begin{array}{c}\text { Gall } \\
\text { index } \\
\end{array}$ & Accession & $\begin{array}{r}\begin{array}{l}\text { Number } \\
\text { of galls }\end{array}{ }^{1,2} \\
\end{array}$ & Accession & $\begin{array}{l}\begin{array}{l}\text { Number } \\
\text { of eggs } 1,2\end{array} \\
\end{array}$ & Accession & $\begin{array}{c}\begin{array}{c}\text { Reproduction } \\
\text { factor }^{3}\end{array} \\
\end{array}$ \\
\hline CNPH 1288 & $1.34 \mathrm{a}$ & CNPH 1288 & $5.59 \mathrm{a}$ & CNPH 0499 & $2498 \mathrm{a}$ & CNPH 0499 & $3.52 \mathrm{a}$ \\
\hline CNPH 1290 & $1.59 \mathrm{a}$ & CNPH 0409 & $6.67 \mathrm{a}$ & CNPH 1298 & $2654 \mathrm{a}$ & CNPH 1298 & $3.74 \mathrm{a}$ \\
\hline CNPH 0102 & $1.80 \mathrm{a}$ & CNPH 0698 & $7.49 \mathrm{a}$ & CNPH 1226 & $2991 \mathrm{a}$ & CNPH 1226 & $4.22 \mathrm{a}$ \\
\hline CNPH 1185 & $1.82 \mathrm{a}$ & CNPH 1454 & $7.53 \mathrm{a}$ & CNPH 0409 & $3500 \mathrm{a}$ & CNPH 0409 & $4.93 \mathrm{a}$ \\
\hline CNPH 1260 & $1.87 \mathrm{a}$ & CNPH 0707 & $7.76 \mathrm{a}$ & CNPH 0866 & $3707 \mathrm{a}$ & CNPH 0866 & $5.22 \mathrm{a}$ \\
\hline CNPH 1226 & $1.88 \mathrm{a}$ & CNPH 1225 & $8.38 \mathrm{a}$ & CNPH 1260 & $4250 \mathrm{a}$ & CNPH 1260 & $5.99 \mathrm{a}$ \\
\hline CNPH 1249 & $1.93 \mathrm{a}$ & CNPH 1260 & $8.64 \mathrm{a}$ & CNPH 1120 & $4434 \mathrm{a}$ & CNPH 1120 & $6.24 \mathrm{a}$ \\
\hline CNPH 1034 & $1.94 \mathrm{a}$ & CNPH 0017 & $8.84 \mathrm{a}$ & CNPH 1456 & $4833 \mathrm{a}$ & CNPH 1456 & $6.81 \mathrm{a}$ \\
\hline CNPH 1238 & $2.00 \mathrm{a}$ & CNPH 1607 & $8.90 \mathrm{a}$ & CNPH 0398 & $5000 \mathrm{a}$ & CNPH 0398 & $7.05 \mathrm{a}$ \\
\hline CNPH 1195 & $2.00 \mathrm{a}$ & CNPH 1238 & $9.00 \mathrm{a}$ & CNPH 0698 & $5350 \mathrm{a}$ & CNPH 0698 & $7.54 \mathrm{a}$ \\
\hline CNPH 1092 & $2.04 \mathrm{a}$ & CNPH 1048 & $9.47 \mathrm{a}$ & CNPH 0663 & $5371 \mathrm{a}$ & CNPH 0663 & $7.57 \mathrm{a}$ \\
\hline CNPH 1022 & $2.10 \mathrm{a}$ & CNPH 1226 & $9.50 \mathrm{a}$ & CNPH 0865 & $5504 \mathrm{a}$ & CNPH 0865 & $7.75 \mathrm{a}$ \\
\hline CNPH 0899 & $2.13 \mathrm{a}$ & CNPH 1092 & $9.53 \mathrm{a}$ & CNPH 0017 & $5798 \mathrm{a}$ & CNPH 0017 & $8.17 \mathrm{a}$ \\
\hline CNPH 0798 & $2.17 \mathrm{a}$ & CNPH 1185 & $10.55 \mathrm{a}$ & CNPH 0390 & $5807 \mathrm{a}$ & CNPH 0390 & $8.18 \mathrm{a}$ \\
\hline CNPH 0409 & $2.17 \mathrm{a}$ & CNPH 0969 & $10.67 \mathrm{a}$ & CNPH 0955 & $5807 \mathrm{a}$ & CNPH 0955 & $8.18 \mathrm{a}$ \\
\hline CNPH 0969 & $2.17 \mathrm{a}$ & CNPH 1246 & $10.88 \mathrm{a}$ & CNPH 1454 & $5833 \mathrm{a}$ & CNPH 1454 & $8.22 \mathrm{a}$ \\
\hline CNPH 1048 & $2.20 \mathrm{a}$ & CNPH 0798 & $11.25 \mathrm{a}$ & CNPH 0784 & 5917 a & CNPH 0784 & $8.34 \mathrm{a}$ \\
\hline CNPH 0602 & $2.25 \mathrm{a}$ & CNPH 1561 & $11.30 \mathrm{a}$ & CNPH 0899 & $6208 \mathrm{a}$ & CNPH 0899 & $8.75 \mathrm{a}$ \\
\hline CNPH 0417 & $2.25 \mathrm{a}$ & CNPH 0181 & $11.40 \mathrm{a}$ & CNPH 0182 & $6336 \mathrm{a}$ & CNPH 0182 & $8.92 \mathrm{a}$ \\
\hline CNPH 0181 & $2.29 \mathrm{a}$ & CNPH 0019 & $11.56 \mathrm{a}$ & CNPH 1238 & $6400 \mathrm{a}$ & CNPH 1238 & $9.02 \mathrm{a}$ \\
\hline CNPH 1124 & $2.32 \mathrm{a}$ & CNPH 0102 & $11.72 \mathrm{a}$ & CNPH 1195 & $6633 \mathrm{a}$ & CNPH 1195 & $9.34 \mathrm{a}$ \\
\hline CNPH 0423 & $2.32 \mathrm{a}$ & CNPH 0182 & $11.76 \mathrm{a}$ & CNPH 0184 & $6694 \mathrm{a}$ & CNPH 0184 & $9.43 \mathrm{a}$ \\
\hline CNPH 0780 & $2.34 \mathrm{a}$ & CNPH 0156 & $12.07 \mathrm{a}$ & CNPH 1246 & $6725 \mathrm{a}$ & CNPH 1246 & $9.47 \mathrm{a}$ \\
\hline CNPH 0876 & $2.42 \mathrm{a}$ & CNPH 0733 & $12.10 \mathrm{a}$ & CNPH 1056 & $6731 \mathrm{a}$ & CNPH 1056 & $9.49 \mathrm{a}$ \\
\hline CNPH 0724 & $2.43 \mathrm{a}$ & CNPH 1039 & $12.50 \mathrm{a}$ & CNPH 0181 & $6750 a$ & CNPH 0181 & $9.51 \mathrm{a}$ \\
\hline CNPH 1521 & $2.44 \mathrm{a}$ & CNPH 1290 & $12.50 \mathrm{a}$ & CNPH 0402 & $6857 \mathrm{a}$ & CNPH 0402 & $9.66 \mathrm{a}$ \\
\hline CNPH 1224 & $2.48 \mathrm{a}$ & CNPH 0865 & $12.73 \mathrm{a}$ & CNPH 1048 & $6880 \mathrm{a}$ & CNPH 1048 & $9.69 \mathrm{a}$ \\
\hline CNPH 1011 & $2.50 \mathrm{a}$ & CNPH 1121 & $12.75 \mathrm{a}$ & CNPH 0717 & $7071 \mathrm{a}$ & CNPH 0717 & $9.96 \mathrm{a}$ \\
\hline CNPH 0945 & $2.50 \mathrm{a}$ & CNPH 0117 & $12.79 \mathrm{a}$ & CNPH 1289 & $7164 \mathrm{a}$ & CNPH 1289 & $10.09 \mathrm{a}$ \\
\hline CNPH 1035 & $2.50 \mathrm{a}$ & CNPH 0876 & $13.09 \mathrm{a}$ & CNPH 0798 & $7167 \mathrm{a}$ & CNPH 0798 & $10.09 \mathrm{a}$ \\
\hline CNPH 0045 & $2.55 \mathrm{a}$ & CNPH 1522 & $13.29 \mathrm{a}$ & CNPH 0790 & 7429 a & CNPH 0790 & $10.47 \mathrm{a}$ \\
\hline CNPH 0202 & $2.57 \mathrm{a}$ & CNPH 1195 & $13.40 \mathrm{a}$ & CNPH 1526 & 7629 a & CNPH 1526 & $10.75 \mathrm{a}$ \\
\hline CNPH 0182 & $2.57 \mathrm{a}$ & CNPH 0945 & $13.50 \mathrm{a}$ & CNPH 1225 & 8007 a & CNPH 1225 & $11.28 \mathrm{a}$ \\
\hline CNPH 0784 & $2.60 \mathrm{a}$ & CNPH 1022 & $13.70 \mathrm{a}$ & CNPH 1607 & 8500 a & CNPH 1607 & $11.98 \mathrm{a}$ \\
\hline CNPH 0698 & $2.65 \mathrm{a}$ & CNPH 1298 & $14.34 \mathrm{~b}$ & CNPH 1521 & 8514 a & CNPH 1521 & $12.00 \mathrm{a}$ \\
\hline CNPH 0534 & $2.65 \mathrm{a}$ & CNPH 0866 & $14.57 \mathrm{~b}$ & CNPH 0268 & $8571 \mathrm{a}$ & CNPH 0268 & $12.08 \mathrm{a}$ \\
\hline CNPH 0499 & $2.67 \mathrm{a}$ & CNPH 0378 & $14.60 \mathrm{~b}$ & CNPH 1121 & 8800 a & CNPH 1121 & $12.40 \mathrm{a}$ \\
\hline CNPH 1522 & $2.69 \mathrm{a}$ & CNPH 1560 & $14.73 \mathrm{~b}$ & CNPH 0969 & 9198 a & CNPH 0969 & $12.96 \mathrm{a}$ \\
\hline CNPH 0419 & $2.69 \mathrm{a}$ & CNPH 1514 & $14.92 \mathrm{~b}$ & CNPH 0117 & 9214 a & CNPH 0117 & $12.98 \mathrm{a}$ \\
\hline CNPH 1225 & $2.69 \mathrm{a}$ & CNPH 0602 & $15.14 \mathrm{~b}$ & CNPH 0803 & 9273 a & CNPH 0803 & $13.09 \mathrm{a}$ \\
\hline CNPH 0733 & $2.70 \mathrm{a}$ & CNPH 1056 & $15.29 \mathrm{~b}$ & CNPH 1039 & $9600 \mathrm{a}$ & CNPH 1039 & $13.52 \mathrm{a}$ \\
\hline CNPH 0376 & $2.73 \mathrm{a}$ & CNPH 0376 & $15.37 \mathrm{~b}$ & CNPH 0019 & 9765 a & CNPH 0019 & $13.76 \mathrm{a}$ \\
\hline CNPH 1246 & $2.73 \mathrm{a}$ & CNPH 0790 & $15.41 \mathrm{~b}$ & CNPH 0113 & 9863 a & CNPH 0113 & $13.89 \mathrm{a}$ \\
\hline CNPH 1121 & $2.75 \mathrm{a}$ & CNPH 0499 & $15.42 \mathrm{~b}$ & CNPH 0156 & 9996 a & CNPH 0156 & $14.08 \mathrm{a}$ \\
\hline
\end{tabular}


Table 1. continued....

\begin{tabular}{|c|c|c|c|c|c|c|c|}
\hline Accession & $\begin{array}{c}\text { Gall } \\
\text { index }\end{array}$ & Accession & $\begin{array}{l}\text { Number } \\
\text { of galls }{ }^{1,2}\end{array}$ & Accession & $\begin{array}{l}\text { Number } \\
\text { of eggs }{ }^{1,2}\end{array}$ & Accession & $\begin{array}{c}\text { Reproduction } \\
\text { factor }^{3}\end{array}$ \\
\hline CNPH 1148 & $2.77 \mathrm{a}$ & CNPH 0784 & $15.54 \mathrm{~b}$ & CNPH 0378 & $10042 \mathrm{a}$ & CNPH 0378 & $14.14 \mathrm{a}$ \\
\hline CNPH 0402 & $2.79 \mathrm{a}$ & CNPH 1521 & $15.86 \mathrm{~b}$ & CNPH 1035 & $10050 \mathrm{a}$ & CNPH 1035 & $14.16 \mathrm{a}$ \\
\hline CNPH 0790 & $2.81 \mathrm{a}$ & CNPH 0398 & $15.90 \mathrm{~b}$ & CNPH 0045 & $10054 \mathrm{~b}$ & CNPH 0045 & $14.16 \mathrm{~b}$ \\
\hline CNPH 0707 & $2.82 \mathrm{a}$ & CNPH 1249 & $16.10 \mathrm{~b}$ & CNPH 1560 & $10071 \mathrm{~b}$ & CNPH 1560 & $14.19 b$ \\
\hline CNPH 0006 & $2.82 \mathrm{a}$ & CNPH 1250 & $16.14 \mathrm{~b}$ & CNPH 1250 & $10300 \mathrm{~b}$ & CNPH 1250 & $14.51 \mathrm{~b}$ \\
\hline CNPH 0117 & $2.82 \mathrm{a}$ & CNPH 1123 & $16.21 \mathrm{~b}$ & CNPH 0095 & $10673 \mathrm{~b}$ & CNPH 0095 & $15.04 \mathrm{~b}$ \\
\hline CNPH 0398 & $2.85 \mathrm{a}$ & CNPH 0899 & $16.34 \mathrm{~b}$ & CNPH 0780 & $11250 \mathrm{~b}$ & CNPH 0780 & $15.85 \mathrm{~b}$ \\
\hline CNPH 1514 & $2.88 \mathrm{~b}$ & CNPH 0717 & $16.41 \mathrm{~b}$ & CNPH 1092 & $11273 \mathrm{~b}$ & CNPH 1092 & $15.88 \mathrm{~b}$ \\
\hline CNPH 0378 & $2.89 \mathrm{~b}$ & Santa Cruz & $16.86 \mathrm{~b}$ & CNPH 1565 & $11367 \mathrm{~b}$ & CNPH 1565 & $16.01 \mathrm{~b}$ \\
\hline CNPH 1289 & $2.89 \mathrm{~b}$ & CNPH 0419 & $16.86 \mathrm{~b}$ & CNPH 0643 & $11667 \mathrm{~b}$ & CNPH 0643 & $16.43 \mathrm{~b}$ \\
\hline CNPH 1056 & $2.90 \mathrm{~b}$ & CNPH 1034 & $17.01 \mathrm{~b}$ & CNPH 1522 & $11750 \mathrm{~b}$ & CNPH 1522 & $16.55 \mathrm{~b}$ \\
\hline CNPH 0017 & $2.92 \mathrm{~b}$ & CNPH 1224 & $17.13 \mathrm{~b}$ & CNPH 0668 & $11916 \mathrm{~b}$ & CNPH 0668 & $16.79 \mathrm{~b}$ \\
\hline CNPH 1556 & $2.94 \mathrm{~b}$ & CNPH 1124 & $17.32 \mathrm{~b}$ & CNPH 1556 & $11946 \mathrm{~b}$ & CNPH 1556 & $16.83 \mathrm{~b}$ \\
\hline CNPH 0095 & $2.98 \mathrm{~b}$ & CNPH 0457 & $17.69 \mathrm{~b}$ & CNPH 1438 & $12067 \mathrm{~b}$ & CNPH 1438 & $17.00 \mathrm{~b}$ \\
\hline CNPH 1561 & $2.98 \mathrm{~b}$ & CNPH 1227 & $17.75 \mathrm{~b}$ & CNPH 1011 & $12125 \mathrm{~b}$ & CNPH 1011 & $17.08 \mathrm{~b}$ \\
\hline CNPH 1123 & $2.98 \mathrm{~b}$ & CNPH 0789 & $17.79 \mathrm{~b}$ & CNPH 0638 & $12175 b$ & CNPH 0638 & $17.15 b$ \\
\hline CNPH 0638 & $2.98 \mathrm{~b}$ & CNPH 0871 & $17.84 \mathrm{~b}$ & CNPH 1561 & $12180 \mathrm{~b}$ & CNPH 1561 & $17.15 b$ \\
\hline CNPH 1039 & $3.00 \mathrm{~b}$ & CNPH 0750 & $17.98 \mathrm{~b}$ & CNPH 1563 & $12251 \mathrm{~b}$ & CNPH 1563 & $17.26 \mathrm{~b}$ \\
\hline CNPH 0866 & $3.01 \mathrm{~b}$ & CNPH 0417 & $18.00 \mathrm{~b}$ & CNPH 0707 & $12727 \mathrm{~b}$ & CNPH 0707 & $17.93 \mathrm{~b}$ \\
\hline CNPH 1607 & $3.05 \mathrm{~b}$ & CNPH 1035 & $18.08 \mathrm{~b}$ & CNPH 0610 & $13142 b$ & CNPH 0610 & $18.51 \mathrm{~b}$ \\
\hline CNPH 0508 & $3.06 \mathrm{~b}$ & CNPH 1526 & $18.19 \mathrm{~b}$ & CNPH 1290 & $13317 \mathrm{~b}$ & CNPH 1290 & $18.76 \mathrm{~b}$ \\
\hline CNPH 1515 & $3.07 \mathrm{~b}$ & CNPH 0668 & $18.42 \mathrm{~b}$ & CNPH 1288 & $13750 \mathrm{~b}$ & CNPH 1288 & $19.37 \mathrm{~b}$ \\
\hline CNPH 0803 & $3.09 \mathrm{~b}$ & CNPH 0643 & $18.47 \mathrm{~b}$ & CNPH 0945 & $14375 \mathrm{~b}$ & CNPH 0945 & $20.25 b$ \\
\hline CNPH 0457 & $3.11 \mathrm{~b}$ & CNPH 1563 & $18.54 \mathrm{~b}$ & CNPH 1514 & $14396 b$ & CNPH 1514 & $20.28 b$ \\
\hline CNPH 1020 & $3.13 \mathrm{~b}$ & CNPH 0390 & $18.69 \mathrm{~b}$ & CNPH 0875 & $14517 \mathrm{~b}$ & CNPH 0875 & $20.45 b$ \\
\hline CNPH 0156 & $3.13 \mathrm{~b}$ & CNPH 0955 & $18.69 \mathrm{~b}$ & CNPH 0534 & $14529 \mathrm{~b}$ & CNPH 0534 & $20.47 \mathrm{~b}$ \\
\hline CNPH 1298 & $3.13 \mathrm{~b}$ & CNPH 0045 & $18.82 \mathrm{~b}$ & CNPH 0724 & $14593 \mathrm{~b}$ & CNPH 0724 & $20.56 \mathrm{~b}$ \\
\hline Santa Cruz & $3.14 \mathrm{~b}$ & CNPH 0423 & $18.82 \mathrm{~b}$ & CNPH 1022 & $14900 \mathrm{~b}$ & CNPH 1022 & $20.99 b$ \\
\hline CNPH 0789 & $3.15 \mathrm{~b}$ & CNPH 1011 & $18.92 \mathrm{~b}$ & CNPH 0602 & $15171 \mathrm{~b}$ & CNPH 0602 & $21.37 \mathrm{~b}$ \\
\hline CNPH 1438 & $3.17 \mathrm{~b}$ & CNPH 1289 & $19.17 \mathrm{~b}$ & CNPH 1185 & $15353 b$ & CNPH 1185 & $21.63 b$ \\
\hline CNPH 0871 & $3.17 \mathrm{~b}$ & CNPH 1438 & $19.25 \mathrm{~b}$ & CNPH 0313 & $15521 \mathrm{~b}$ & CNPH 0313 & $21.86 \mathrm{~b}$ \\
\hline CNPH 0113 & $3.19 \mathrm{~b}$ & CNPH 0402 & $19.56 \mathrm{~b}$ & CNPH 0418 & $15719 b$ & CNPH 0418 & $22.14 b$ \\
\hline CNPH 1250 & $3.20 \mathrm{~b}$ & CNPH 0534 & $19.57 \mathrm{~b}$ & CNPH 0487 & $15767 \mathrm{~b}$ & CNPH 0487 & $22.20 \mathrm{~b}$ \\
\hline CNPH 0268 & $3.22 \mathrm{~b}$ & CNPH 0113 & $19.98 \mathrm{~b}$ & CNPH 0789 & $15871 \mathrm{~b}$ & CNPH 0789 & $22.36 \mathrm{~b}$ \\
\hline CNPH 0418 & $3.25 \mathrm{~b}$ & CNPH 0663 & $20.51 \mathrm{~b}$ & CNPH 0417 & $16000 \mathrm{~b}$ & CNPH 0417 & $22.54 \mathrm{~b}$ \\
\hline CNPH 0955 & $3.27 \mathrm{~b}$ & CNPH 0724 & $20.52 b$ & Santa Cruz & $16080 \mathrm{~b}$ & Santa Cruz & $22.65 b$ \\
\hline CNPH 0390 & $3.27 \mathrm{~b}$ & CNPH 0638 & $21.07 \mathrm{~b}$ & CNPH 0876 & $16150 \mathrm{~b}$ & CNPH 0876 & $22.75 b$ \\
\hline CNPH 1454 & $3.30 \mathrm{~b}$ & CNPH 0313 & $21.53 \mathrm{~b}$ & CNPH 1135 & $17944 \mathrm{~b}$ & CNPH 1135 & $25.27 \mathrm{~b}$ \\
\hline CNPH 0313 & $3.31 \mathrm{~b}$ & CNPH 0803 & $21.59 \mathrm{~b}$ & CNPH 0457 & $18340 \mathrm{~b}$ & CNPH 0457 & $25.83 b$ \\
\hline CNPH 0610 & $3.36 \mathrm{~b}$ & CNPH 1020 & $21.63 \mathrm{~b}$ & CNPH 1123 & $19072 \mathrm{~b}$ & CNPH 1123 & $26.87 \mathrm{~b}$ \\
\hline CNPH 0487 & $3.37 \mathrm{~b}$ & CNPH 1148 & $22.00 \mathrm{~b}$ & CNPH 1249 & $19158 \mathrm{~b}$ & CNPH 1249 & $26.99 \mathrm{~b}$ \\
\hline CNPH 0865 & $3.37 \mathrm{~b}$ & CNPH 0508 & $23.01 \mathrm{~b}$ & CNPH 1020 & $19221 b$ & CNPH 1020 & $27.08 \mathrm{~b}$ \\
\hline CNPH 1456 & $3.38 \mathrm{~b}$ & CNPH 1565 & $23.47 \mathrm{~b}$ & CNPH 0419 & $19256 \mathrm{~b}$ & CNPH 0419 & $27.12 b$ \\
\hline CNPH 1526 & $3.48 \mathrm{~b}$ & CNPH 0006 & $24.68 \mathrm{~b}$ & CNPH 1515 & $20138 b$ & CNPH 1515 & $28.37 \mathrm{~b}$ \\
\hline CNPH 0643 & $3.49 \mathrm{~b}$ & CNPH 0487 & $24.87 \mathrm{~b}$ & CNPH 0750 & $20671 \mathrm{~b}$ & CNPH 0750 & $29.12 b$ \\
\hline CNPH 0750 & $3.50 \mathrm{~b}$ & CNPH 1456 & $24.88 \mathrm{~b}$ & CNPH 0423 & $20884 \mathrm{~b}$ & CNPH 0423 & $29.42 \mathrm{~b}$ \\
\hline
\end{tabular}


Table 1. continued....

\begin{tabular}{|c|c|c|c|c|c|c|c|}
\hline Accession & $\begin{array}{c}\text { Gall } \\
\text { index } x^{1,2,3}\end{array}$ & Accession & $\begin{array}{l}\text { Number } \\
\text { of galls }{ }^{1,2}\end{array}$ & Accession & $\begin{array}{l}\text { Number } \\
\text { of eggs }{ }^{1,2}\end{array}$ & Accession & $\begin{array}{c}\text { Reproduction } \\
\text { factor }^{3}\end{array}$ \\
\hline CNPH 1227 & $3.50 \mathrm{~b}$ & CNPH 0095 & $25.00 \mathrm{~b}$ & CNPH 1124 & $21063 b$ & CNPH 1124 & $29.67 \mathrm{~b}$ \\
\hline CNPH 1563 & $3.54 \mathrm{~b}$ & CNPH 0184 & $25.22 \mathrm{~b}$ & CNPH 1034 & $21115 b$ & CNPH 1034 & $29.74 \mathrm{~b}$ \\
\hline CNPH 1135 & $3.57 \mathrm{~b}$ & CNPH 0418 & $25.44 \mathrm{~b}$ & CNPH 1224 & $21375 b$ & CNPH 1224 & $30.11 \mathrm{~b}$ \\
\hline CNPH 0019 & $3.57 \mathrm{~b}$ & CNPH 1515 & $25.50 \mathrm{~b}$ & CNPH 0376 & $21889 \mathrm{~b}$ & CNPH 0376 & $30.83 \mathrm{~b}$ \\
\hline CNPH 0717 & $3.79 \mathrm{~b}$ & CNPH 0875 & $25.72 \mathrm{~b}$ & CNPH 1227 & $22350 \mathrm{~b}$ & CNPH 1227 & $31.48 \mathrm{~b}$ \\
\hline CNPH 0663 & $3.82 \mathrm{~b}$ & CNPH 0268 & $26.00 \mathrm{~b}$ & CNPH 0871 & $23243 b$ & CNPH 0871 & $32.74 \mathrm{~b}$ \\
\hline CNPH 1565 & $3.91 \mathrm{~b}$ & CNPH 1135 & $26.40 \mathrm{~b}$ & CNPH 0102 & $24667 \mathrm{~b}$ & CNPH 0102 & $34.74 \mathrm{~b}$ \\
\hline CNPH 0875 & $3.95 \mathrm{~b}$ & CNPH 0610 & $26.57 \mathrm{~b}$ & CNPH 1148 & $26592 \mathrm{~b}$ & CNPH 1148 & $37.46 \mathrm{~b}$ \\
\hline CNPH 1560 & $4.06 \mathrm{~b}$ & CNPH 1556 & $26.88 \mathrm{~b}$ & CNPH 0733 & $26707 \mathrm{~b}$ & CNPH 0733 & $37.61 \mathrm{~b}$ \\
\hline CNPH 0668 & $4.44 \mathrm{~b}$ & CNPH 1120 & $28.64 \mathrm{~b}$ & CNPH 0202 & $27117 \mathrm{~b}$ & CNPH 0202 & $38.19 \mathrm{~b}$ \\
\hline CNPH 1120 & $4.53 \mathrm{~b}$ & CNPH 0202 & $29.13 \mathrm{~b}$ & CNPH 0508 & $28655 \mathrm{~b}$ & CNPH 0508 & $40.36 \mathrm{~b}$ \\
\hline CNPH 0184 & $4.63 \mathrm{~b}$ & CNPH 0780 & $29.53 \mathrm{~b}$ & CNPH 0006 & $37833 \mathrm{~b}$ & CNPH 0006 & $53.29 \mathrm{~b}$ \\
\hline Mean & 2.85 & & 16.73 & & 12289 & & 17.31 \\
\hline CV (\%) & 20.38 & & 2.26 & & 5.0 & & 17.43 \\
\hline
\end{tabular}

${ }^{1}$ Means within a column followed by same letters do not differ significantly at $5 \%$ level, Scott-Knott's cluster analysis; ${ }^{2}$ Data transformation $[\ln (y)]$ using Box \& Cox (1964) method; ${ }^{3}$ Reproduction factor $(\mathrm{RF}=$ Final nematode population/Initial population), $\mathrm{RF}>1.0=$ susceptible reaction; ${ }^{3}$ Gall index $=$ Values from 1.0 to 1.6 indicate high resistance; from 1.7 to 2.3 indicate resistant genotype; from 2.4 to 3.0 , moderate level of resistance; from 3.1 to 4.0 indicate susceptible reaction; from 4.1 a 5.0 indicate highly susceptible.

significant lower number of eggs when compared to the standard susceptible tomato 'Santa Cruz'. Seven of them [ $S$. lycopersicum 'Venus' (= CNPH 0181), S. lycopersicum 'Cannery Row' $=\mathrm{CNPH}$ 0969), S. lycopersicum 'Hawaii-7996' (= CNPH 1048), S. lycopersicum 'CNPH 1226', S. chilense 'LA 1963' (= CNPH 1238), S. lycopersicum 'PI 126428' (= CNPH 1260), and $S$. pennellii 'LA-0416' (= CNPH 409)] also displayed significant lower values for gall index and gall number (Table 1). The trait low number of nematode eggs is very important in tomato breeding for resistance since it has an epidemiological impact by either avoiding or delaying the pathogen multiplication. The Meloidogyne females can lay eggs for up to three weeks with the average number of around 400 to 500 eggs; in some circumstances, the female lays up to 2,000 eggs (Taylor \& Sasser, 1978). Development and life cycle completion of $M$. enterolobii were observed even in roots of tomato genotypes with the Mi-1 gene (Yang \& Eisenback, 1983; Westerich et al., 2011).

Root-knot nematode resistance is defined by the effects of plant genes that either restrict or prevent multiplication in a given host species (Trudgill, 1991).
In the first assay, the reproduction factor (RF) values ranged from 3.52 to 53.28. In the literature, the susceptible reaction is characterized when a given accession had a mean $\mathrm{RF} \geq 1.0$ and a resistant reaction when $\mathrm{RF}<1.0$. Therefore, under our experimental conditions, no accession could be classified as resistant according to this criterion. However, a group of 47 accessions (Table 1) presented RF values significantly lower than that of the tomato cultivar Santa Cruz $(\mathrm{RF}=$ 22.65 ), a value close to that previously reported to another susceptible tomato cultivar Rutgers $(\mathrm{RF}=17.72)$ (Cantu et al., 2009). In another study, the $M$. enterolobii - S. lycopersicum interaction indicated RF values ranging from 4.80 to 8.40 for cultivars Santa Clara and Santa Cruz, respectively (Melo et al., 2011). Variation of the $M$. enterolobii $\mathrm{RF}$, ranging from 11.34 to 18.21 , was previously observed in a collection of commercial tomato rootstocks carrying the Mi-1 gene (Cantu et al., 2009). The reproduction of $M$. enterolobii and $M$. javanica in a set of rootstocks with the Mi-1 gene ('Magnet' and 'Helper M') was evaluated in another set of experiments using artificial soil infestation with an inoculum pressure of
$500 \mathrm{~J} 2$ per plant. In these two rootstocks, carrying the Mi-1 locus, $M$. javanica was unable to complete its life cycle whereas $M$. enterolobii development was not affected with females laying a profuse amount of eggs, 24 days after inoculation.

Second assay with 20 selected Solanum (Lycopersicon) accessions

Significant differences were observed for the number of galls among accessions (Table 2). The cultivar Yoshimatsu and the accessions $S$. peruvianum 'PI 126408-6' (= CNPH 0102), $S$. lycopersicum 'Cannery Row' (= CNPH 0969), S. lycopersicum 'Ohio 8245' (= CNPH 1246), S. lycopersicum 'PI 126428 ' (= CNPH 1260), S. habrochaites 'PI 126449' (= CNPH 1290), and $S$. peruvianum 'LA 1616' (= CNPH 798) showed significantly lower number of gall differences when compared to the susceptible control 'Santa Cruz'. Cultivar Yoshimatsu showed lowest value (around 3.65 galls per root system). No significant differences were observed among accessions for the trait number of eggs (Table 2). However, in relation to the reproduction factor, the accessions S. lycopersicum 'Ohio 8245 ' $\left(={ }^{\prime} \mathrm{CNPH}\right.$ 
1246') (0.17), 'Yoshimatsu' (0.62), and $S$. pimpinelifolium 'CGO 7650' (= 'CNPH 1195') (1.69) had a significantly superior performance when compared to the susceptible standard 'Santa Cruz' (5.58). According to the classical definition of resistance based upon analysis of the reproduction factor, only the accessions $S$. lycopersicum 'Ohio 8245 ' and 'Yoshimatsu' can be classified as resistant since their values were lower than 1. The Brazilian cultivar Yoshimatsu is derived from multiple crosses involving breeding lines from Hawaii (USA) and French Guiana. This genetic material was released in 1988 after selection to adaptation to the Amazonas Basin region, tolerance to high temperatures, and bacterial wilt (Ralstonia solanacearum) resistance (Souza \& Gentil, 2013).

Plants were conducted in $0.4 \mathrm{~L}$ pots in the second assay, which provided more suitable conditions for development and nutrient uptake. In fact, the overall plant development was visibly more vigorous when compared to the first assay conducted in trays. In this assay S. pennellii LA-416 (= CNPH 409) was found to be susceptible, confirming the reaction previously observed by Melo et al. (2011). The accessions $S$. lycopersicum 'PI-126428' (= CNPH 1260) as well as S. peruvianum 'PI
126408' (= CNPH 0102), S. peruvianum 'CNPH 0602', S. lycopersicum 'Ohio 8245 ' (= CNPH 1246), S. habrochaites 'PI 247087' (= CNPH 1288), S. habrochaites 'PI 126449' (= CNPH 1290), S. lycopersicum 'LA-3043' (= CNPH 1521), S. peruvianum 'LA-1616' $(=\mathrm{CNPH}$ 0798) and S. pimpinellifolium 'CGO 7650' (= CNPH 1195) displayed superior levels of resistance to $M$. enterolobii in both assays. Therefore, these results indicated that some Solanum (sect. Lycopersicon) accessions may have a stable phenotypic expression of resistance to $M$. enterolobii. All these genotypes might be considered useful genetic sources for tomato breeding

Table 2. Number of galls; number of eggs; and reproduction factor values of 20 Solanum (section Lycopersicon) accessions and the susceptible and resistant standard cultivars S. lycopersicum 'Santa Cruz' and 'Yoshimatsu'; respectively evaluation under Meloidogyne enterolobii inoculation. Evaluation was carried out 45 days after inoculation. Recife, UFRPE, 2013.

\begin{tabular}{|c|c|c|c|c|c|c|}
\hline Accession & $\begin{array}{c}\text { Number of } \\
\text { galls }{ }^{1,2}\end{array}$ & Accession & $\begin{array}{c}\text { Number of } \\
\text { eggs }^{1,3}\end{array}$ & Accession & $\begin{array}{l}\text { Reproduction } \\
\text { factor }^{1,4,5}\end{array}$ & $\mathbf{R F}^{6}$ \\
\hline Yoshimatsu & $3.67 \mathrm{a}$ & CNPH 1246 & $550 \mathrm{a}$ & CNPH 1246 & $0.17 \mathrm{a}$ & $\mathrm{R}$ \\
\hline CNPH 0102 & $6.39 \mathrm{a}$ & Yoshimatsu & $2056 \mathrm{a}$ & Yoshimatsu & $0.62 \mathrm{a}$ & $\mathrm{R}$ \\
\hline CNPH 1290 & $10.61 \mathrm{a}$ & CNPH 1195 & $5584 \mathrm{a}$ & CNPH 1195 & $1.69 \mathrm{a}$ & S \\
\hline CNPH 0969 & $11.17 \mathrm{a}$ & CNPH 0602 & 9798 a & CNPH 0602 & $2.97 \mathrm{~b}$ & $\mathrm{~S}$ \\
\hline CNPH 1260 & $12.67 \mathrm{a}$ & CNPH 1521 & $13083 \mathrm{a}$ & CNPH 1521 & $3.97 \mathrm{~b}$ & $\mathrm{~S}$ \\
\hline CNPH 1246 & $13.33 \mathrm{a}$ & CNPH 1288 & $13631 \mathrm{a}$ & CNPH 1288 & $4.13 \mathrm{~b}$ & S \\
\hline CNPH 0798 & $16.56 \mathrm{a}$ & CNPH 1260 & $13850 \mathrm{a}$ & CNPH 1260 & $4.20 \mathrm{~b}$ & $\mathrm{~S}$ \\
\hline CNPH 1288 & $19.58 \mathrm{~b}$ & CNPH 0698 & $14650 \mathrm{a}$ & CNPH 0698 & $4.44 \mathrm{~b}$ & $\mathrm{~S}$ \\
\hline Santa Cruz & $20.67 \mathrm{~b}$ & CNPH 0102 & $15278 \mathrm{a}$ & CNPH 0102 & $4.63 \mathrm{~b}$ & $\mathrm{~S}$ \\
\hline CNPH 0707 & $21.61 \mathrm{~b}$ & CNPH 0707 & $15333 \mathrm{a}$ & CNPH 0707 & $4.65 \mathrm{~b}$ & S \\
\hline CNPH 0698 & $21.67 \mathrm{~b}$ & CNPH 0876 & $15478 \mathrm{a}$ & CNPH 0876 & $4.69 \mathrm{~b}$ & $\mathrm{~S}$ \\
\hline CNPH 1092 & $24.11 \mathrm{~b}$ & CNPH 0969 & $16183 \mathrm{a}$ & CNPH 0969 & $4.90 \mathrm{~b}$ & $\mathrm{~S}$ \\
\hline CNPH 1048 & $24.67 \mathrm{~b}$ & Santa Cruz & $18417 \mathrm{a}$ & Santa Cruz & $5.58 \mathrm{~b}$ & $\mathrm{~S}$ \\
\hline CNPH 1521 & $24.72 \mathrm{~b}$ & CNPH 1185 & $18550 \mathrm{a}$ & CNPH 1185 & $5.62 \mathrm{~b}$ & S \\
\hline CNPH 0899 & $28.00 \mathrm{~b}$ & CNPH 1225 & 19458 a & CNPH 1225 & $5.90 \mathrm{~b}$ & S \\
\hline CNPH 0602 & $30.67 \mathrm{~b}$ & CNPH 1290 & $21690 \mathrm{a}$ & CNPH 1290 & $6.57 \mathrm{~b}$ & S \\
\hline CNPH 0409 & $31.00 \mathrm{~b}$ & CNPH 0409 & 24539 a & CNPH 0409 & $7.44 \mathrm{~b}$ & $\mathrm{~S}$ \\
\hline CNPH 0876 & $31.72 \mathrm{~b}$ & CNPH 1048 & $24608 \mathrm{a}$ & CNPH 1048 & $7.46 \mathrm{~b}$ & S \\
\hline CNPH 1225 & $32.89 \mathrm{~b}$ & CNPH 0499 & $25989 a$ & CNPH 0499 & $7.87 \mathrm{~b}$ & S \\
\hline CNPH 1185 & $35.00 \mathrm{~b}$ & CNPH 0899 & $26378 \mathrm{a}$ & CNPH 0899 & $7.99 \mathrm{~b}$ & $\mathrm{~S}$ \\
\hline CNPH 1195 & $43.44 \mathrm{~b}$ & CNPH 1092 & 26769 a & CNPH 1092 & $8.11 \mathrm{~b}$ & $\mathrm{~S}$ \\
\hline CNPH 0499 & $50.83 \mathrm{~b}$ & CNPH 0798 & $27779 \mathrm{a}$ & CNPH 0798 & $8.41 \mathrm{~b}$ & $\mathrm{~S}$ \\
\hline $\bar{X}^{(7)}$ & 22.90 & & 16802 & & 53.40 & \\
\hline CV (\%) & 29.46 & & 41.16 & & 5.09 & \\
\hline
\end{tabular}

${ }^{1}$ Means within a column followed by same letters do not differ significantly at $5 \%$ level, Scott-Knott's cluster analysis; ${ }^{2}$ Data transformation $[\ln (y)]$ using Box \& Cox (1964) method; ${ }^{3}$ Data transformation [ $\left.(y+0.5)^{\wedge} 0.5\right]$ using the Box \& Cox (1964) method; ${ }^{4}$ Data transformation $[\ln (y+0.5)]$ using the Yamamura $(1999)$ method; ${ }^{5}$ Reproduction factor $(\mathrm{RF}=$ Final nematode population/Initial population $) ;{ }^{6} \mathrm{RF}>1.0=$ susceptible reaction; ${ }^{7} \bar{X}=$ overall mean. 
Table 3. Reaction of tomato accessions to Meloidogyne incognita race 1, M. javanica, and M. enterolobii. Brasília, Embrapa Hortaliças, 2014.

\begin{tabular}{|c|c|c|c|c|c|}
\hline \multirow[b]{2}{*}{ Tomato accessions } & \multicolumn{5}{|c|}{ Meloidogyne enterolobii } \\
\hline & Gall Index & Egg mass index & $\begin{array}{c}\text { Number of galls/ } \\
\text { gram of root }\end{array}$ & $\begin{array}{l}\text { Reproduction } \\
\text { factor }^{4}\end{array}$ & Reaction $^{1}$ \\
\hline CNPH 522 & $3.8 \mathrm{a}^{4}$ & $3.0 \mathrm{a}$ & $1090.1 \mathrm{a}$ & $5.5 \mathrm{a}$ & $\mathrm{S}$ \\
\hline CNPH 1195 & $4.2 \mathrm{a}$ & $3.5 \mathrm{a}$ & $1870.4 \mathrm{a}$ & $7.7 \mathrm{a}$ & $\mathrm{S}$ \\
\hline CNPH 1246 & $4.5 \mathrm{a}$ & $2.8 \mathrm{a}$ & $1672.1 \mathrm{a}$ & $7.6 \mathrm{a}$ & $\mathrm{S}$ \\
\hline Nemadoro $^{2}$ & $4.2 \mathrm{a}$ & $2.8 \mathrm{a}$ & $1287.7 \mathrm{a}$ & $5.8 \mathrm{a}$ & $\mathrm{S}$ \\
\hline Rutgers $^{3}$ & $4.7 \mathrm{a}$ & $3.3 \mathrm{a}$ & $1026.1 \mathrm{a}$ & $8.5 \mathrm{a}$ & $\mathrm{S}$ \\
\hline Overall Mean & 4.27 & 3.10 & 1389.27 & 7.04 & \\
\hline \multirow[t]{2}{*}{ CV $(\%)$} & 13.53 & 19.08 & 54.46 & 34.26 & \\
\hline & \multicolumn{5}{|c|}{ Meloidogyne javanica } \\
\hline CNPH 522 & $1.0 \mathrm{~d}$ & $1.0 \mathrm{c}$ & $118.2 \mathrm{c}$ & $0.4 \mathrm{~d}$ & $\mathrm{R}$ \\
\hline CNPH 1195 & $3.3 \mathrm{c}$ & $4.0 \mathrm{~b}$ & $4569.3 b$ & $19.4 \mathrm{~b}$ & $\mathrm{~S}$ \\
\hline CNPH 1246 & $4.0 \mathrm{~b}$ & $3.7 \mathrm{~b}$ & $12466.8 \mathrm{a}$ & $11.8 \mathrm{c}$ & $\mathrm{S}$ \\
\hline Nemadoro $^{2}$ & $1.0 \mathrm{~d}$ & $1.0 \mathrm{c}$ & $28.1 \mathrm{c}$ & $0.1 \mathrm{~d}$ & $\mathrm{R}$ \\
\hline Rutgers $^{3}$ & $5.0 \mathrm{a}$ & $4.7 \mathrm{a}$ & $10893.7 \mathrm{a}$ & $83.9 \mathrm{a}$ & $\mathrm{S}$ \\
\hline Overall Mean & 2.87 & 2.86 & 5616.01 & 23.13 & \\
\hline \multirow[t]{2}{*}{$\mathrm{CV}(\%)$} & 8.06 & 17.79 & 65.82 & 24.99 & \\
\hline & \multicolumn{5}{|c|}{ Meloidogyne incognita race 1} \\
\hline CNPH 522 & $1.0 \mathrm{c}$ & $1.0 \mathrm{c}$ & $37.2 \mathrm{c}$ & $0.1 \mathrm{~b}$ & $\mathrm{R}$ \\
\hline CNPH 1195 & $4.7 b$ & $4.0 \mathrm{~b}$ & $6546.5 \mathrm{a}$ & $26.5 \mathrm{a}$ & $\mathrm{S}$ \\
\hline CNPH 1246 & $5.0 \mathrm{a}$ & $3.7 \mathrm{~b}$ & $5676.1 \mathrm{a}$ & $24.9 \mathrm{a}$ & $\mathrm{S}$ \\
\hline Nemadoro $^{2}$ & $1.0 \mathrm{c}$ & $1.0 \mathrm{c}$ & $119.8 \mathrm{c}$ & $0.4 \mathrm{~b}$ & $\mathrm{R}$ \\
\hline Rutgers $^{3}$ & $5.0 \mathrm{a}$ & $4.7 \mathrm{a}$ & $3280.4 b$ & $29.7 \mathrm{a}$ & $\mathrm{S}$ \\
\hline Overall Mean & 3.33 & 2.87 & 3133.11 & 16.34 & \\
\hline $\mathrm{CV}(\%)$ & 6.93 & 15.60 & 59.11 & 51.21 & \\
\hline
\end{tabular}

${ }^{1} \mathrm{I}=$ Immune $(\mathrm{RF}=0) ; \mathrm{R}=$ resistant $(\mathrm{RF}<1)$ and, $\mathrm{S}=$ suscetível $(\mathrm{RF}>1) ;{ }^{2} \mathrm{Resistant}$ control; ${ }^{3}$ Susceptible control; ${ }^{4}$ Means within a column followed by same letters do not differ significantly at $5 \%$ level, Scott-Knott's cluster analysis.

programs since they are not suitable hosts for M. enterolobii.

Third assay: Evaluation of the three most promising Solanum accessions against a distinct $M$. enterolobii population as well as one to one $M$. javanica and $M$. incognita race 1 population

The three most promising accessions (S. lycopersicum 'Yoshimatsu', $S$. lycopersicum 'Ohio 8245', and $S$. pimpinellifolium 'CGO 7650') were reevaluated with a distinct $M$. enterolobii population as well as one $M$. javanica and one $M$. incognita race 1 population under higher inoculum levels (Table 3). 'Yoshimatsu' was found to be resistant to $M$. javanica and $M$. incognita race 1 , but highly susceptible to a distinct $M$. enterolobii population. The other two sources displayed susceptibility to all three nematode species.

Resistant germplasm is the most tolerant and economic management strategy to control plant-parasitic nematodes. However, the presence of variants within species of the genus Meloidogyne that are able to overcome resistance genes and difficulties in identifying resistance genes in plants hamper progress in this area. Additionally, the wellstudied $M i-1$ resistance gene from tomato proved ineffective against $M$. enterolobii (Elling, 2013). However, the results obtained here clearly indicated promising genetic solution to control damages caused by $M$. enterolobii. A subgroup of accessions with superior levels of tolerance to $M$. enterolobii were found in distinct species of the genus Solanum (section Lycopersicon) with special mention to the Brazilian cultivar S. lycopersicum 'Yoshimatsu' and the lines $S$. lycopersicum 'Ohio 8245 ' and $S$. pimpinellifolium 'CGO $7650^{\prime}$.

The accessions $S$. lycopersicum PI$126428, S$. peruvianum 'PI 126408', $S$. peruvianum 'CNPH602', S. habrochaites 'PI-247087', S. habrochaites 'PI126449', S. pimpinelifolium 'LA-3043', and $S$. peruvianum 'LA-1616' displayed intermediate phenotypic responses and could be considered good sources of moderate tolerance to $M$. enterolobii. These accessions might be useful for breeding programs aiming to develop cultivars with genetic tolerance to this 
emerging tomato pathogen. The $M i-1$ gene mediated tolerance is characterized by a localized necrosis of host cells near the invading nematode (Brito et al., 2007; Dropkin, 1969). It will be interesting to investigate which mechanism is associated with the resistance/tolerance sources reported here. Solanum peruvianum is an interesting genetic source since it presented one of the best performances against $M$. enterolobii and also displayed simultaneous resistance to Meloidogyne species in previous assays (Carvalho et al., 2010). The important limitation of the natural genetic factors coming from $S$. peruvianum accessions is that it will demand the employment of embryorescue technique after interspecific crossings, as was done to introgress the $M i-1$ gene from $S$. peruvianum 'PI 128657 ' into S. lycopersicum. However, due to this broad resistance spectrum, this accession is considered a potential multi-resistance source for breeding programs and effort to introgression of this resistance will be worthwhile.

From the preemptive breeding standpoint, the identification of superior levels of tolerance to $M$. enterolobii in the cultivated tomato $S$. lycopersicum 'Yoshimatsu' would allow a more efficient incorporation of the genetic factor(s) into elite tomato inbred lines and hybrids. In this case, the natural crossing barriers between accessions are not present. This pure inbred line would be suitable for inheritance, allelism, and linkage studies. Molecular markers could be used to help to map the resistance factors of the sources reported here and accelerate incorporation/ introgression of these genetic factors. This work might be facilitated by current available complete genome sequence of tomato (The Tomato Genome Consortium, 2012).

\section{ACKNOWLEDGMENTS}

We are thankful to Fundação de Amparo à Ciência e Tecnologia do Estado de Pernambuco (FACEPE) for financial support. We also thank Sérgio Rogério, Bruno Alves, Drielle Silva, Romero Cavalcante, José Edvaldo, and Marcelo Coutinho (undergraduate students of the Agronomy Department, Universidade Federal Rural de Pernambuco) for their skillful help during the course of the experiments.

\section{REFERENCES}

BOITEUX, LS; CHARCHAR, JM. 1996. Genetic resistance to root-knot nematode (Meloidogyne javanica) in eggplant (Solanum melongena). Plant Breeding 115: 198-200.

BONETI, JIS; FERRAZ, S. 1981. Modificação do método de Hussey \& Barker para extração de ovos de Meloidogyne exigua de raízes de cafeeiro. Fitopatologia Brasileira 6: 553.

BRITO, JA; STANLEY, JD; KAUR, R; CETINTAS, R; VITO, M; THIES, JA; DICKSON, DW. 2007. Effects of the Mi1; $N$ and Tabasco genes on infection and reproduction of Meloidogyne mayaguensis on tomato and pepper genotypes. Journal of Nematology 39: 327-332.

CARNEIRO, RMDG; ALMEIDA, MRA. 2001. Técnica de eletroforese usada no estudo de enzimas dos nematoides-das-galhas para identificação de espécies. Nematologia Brasileira 25: 35-44.

CANTU, RR; WILCKEN, SRS; ROSA, JMO; GOTO, R. 2009. Reação de porta-enxertos comerciais de tomateiro a Meloidogyne mayaguensis. Summa Phytopathologica 35: 216-218.

CARVALHO FILHO, JLS; GOMES, LAA; MALUF, WR; OLIVEIRA, RR; COSTA, DS; FEREIRA, S; MONTEIRO, AB; CARVALHO, RRC. 2011. Resistance to Meloidogyne incognita race 1 in the lettuce cultivars Grand Rapids and Salinas-88. Euphytica 182: 199-208.

CARVALHO FILHO, JLS; GOMES, LAA; CARVALHO, RRC. 2012. Incidência de galhas de Meloidogyne incognita raça $1 \mathrm{em}$ progênies de $\mathrm{F}_{2: 3}$ ('Salinas $88^{\prime} x$ 'Colorado') de alface. Scientia Plena 8: 1-7.

CARVALHO, RCP; BOITEUX, LS; FONSECA, MEN; PENDON, JAD; MORIONES, E; MUÑOZ, RF; CHARCHAR, JM; RESENDE, RO. 2010. Multiple resistance to Meloidogyne spp. and to bipartite and monopartite Begomovirus spp. in wild Solanum (Lycopersicon) accessions. Plant Disease 94: 179-185.

CHARCHAR, JM; FONSECA, MEN; PINHEIRO, JB; BOITEUX, LS; EISENBACK, JD. 2010. Epidemics of Meloidogyne brasiliensis in Central Brazil on processing tomato hybrids that have the root-knot nematode $M i$ resistance gene. Plant Disease 94: 781.

DROPKIN, VH. 1969. Cellular responses of plants to nematode infections. Annual Review of Phytopathology 7: 101-122.

ELLING, AA. 2013. Major emerging problems with minor Meloidogyne species. Phytopathology 103:1092-1102.

FERREIRA, DF. 2011. SISVAR: A computer statistical analysis system. Ciência Agrotecnologica 35:1039-1042.

HUSSEY, R; BARKER, K. 1973. A comparison of methods of collecting inocula of Meloidogyne spp.; including a new technique. Plant Disease Reporter 57:1025-1028.

JABLONSKA, B; AMMIRAJU, JS; BHATTARAI, KK; MANTELIN, S; ILARDUYA, OM; ROBERTS, PA; KALOSHIAN, I. 2007. The Mi-9 gene from Solanum arcanum conferring heat-stable resistance to root-knot nematodes is a homolog of Mi-1. Plant Physiology, 143: 1044-1054.

MELO, OD; MALUF, WR; GONÇALVES, RJS; NETO, ACG; GOMES, LAA; CARVALHO RC. 2011. Triagem de genótipos de hortaliças para resistência a Meloidogyne enterolobii. Pesquisa Agropecuária Brasileira 46: 829-835.

MOENS, M; PERRY, RN; STARR, JL. 2009. Meloidogyne Species - A diverse group of novel and important plant parasites. In: PERRY, RN; MOENS, M; STARR, JL (eds). Root-knot nematodes. Cambridge: CAB International. P.1-17.

OOSTENBRINK, M. 1966. Major characteristics of the relation between nematodes and plants. Mededelingen Landbouw 66: 1-46.

PINHEIRO, JB; BOITEUX, LS; LOPES, CA; SILVA, GO. 2009. Identificação de fontes de resistência ao nematóide Meloidogyne mayaguensis em acessos de tomateiro (Solanum secção Lycopersicon). Brasília: EMBRAPA-CNPH (Boletim de Pesquisa e Desenvolvimento 56). $18 \mathrm{p}$.

RAMMAH, A; HIRSCHMANN, H. 1988. Meloidogyne mayaguensis $\mathrm{n}$. sp. (Meloidogynidae); a root-knot nematode from Puerto Rico. Journal of Nematology 20: 58-69.

SAS INSTITUTE INC. 2009. SAS/STAT ${ }^{\circledR}$. User's Guide. $2^{\text {nd }}$ ed. Cary; North Coroline: SAS Institute Inc. 786 p.

SIQUEIRA, KMS; FREITAS, VM; ALMEIDA, MRA; MARCILENE, FAS; CARES, JE; TIGANO, MS; CARNEIRO, RMDG. 2009. Detecção de Meloidogyne mayaguensis em goiabeira e mamoeiro no estado de Goiás, usando marcadores moleculares. Tropical Plant Pathology, 34: 256-260.

SOUZA, LVD; GENTIL, DFDO. 2013. Estaquia da cultivar de tomateiro Yoshimatsu. Horticultura Brasileira 31: 166-170.

TAYLOR, AL; SASSER, JN. 1978. Biology, identification and control of root-knot Nematodes. Internacional Meloidogyne Project. North Carolina: State University; $111 \mathrm{p}$.

THE TOMATO GENOME CONSORTIUM. 2012. The tomato genome sequence provides insights into fleshy fruit evolution. Nature 485: 635-641.

TRUDGILL, DL. 1991. Resistance to and tolerance of plant parasitic nematodes in plants. Annual Review of Phytopathology 29: 167-193.

VEREMIS, JC; ROBERTS, PA. 1996. Relationships between Meloidogyne incognita resistance genes in Lycopersicon peruvianum differentiated by heat sensitivity and nematode virulence. Theoretical and Appllied Genetics 
93: 950-959.

WESTERICH, JN; ROSA, JMO; WILCKEN, SRS. 2011. Comparative study of biology of Meloidogyne enterolobii (= M. mayaguensis) and Meloidogyne javanica in tomatoes with
Mi gene. Summa Phytopathologica 37: 35-41.

YANG, B; EISENBACK, JD. 1983. Meloidogyne enterolobii $\mathrm{n}$. sp. (Meloidogynidae); a rootknot nematode parasitizing pacara earpod tree in China. Journal of Nematology 15: 381-391.

YAMAMURA, K. 1999. Transformation using $(\mathrm{x}+0.5)$ to stabilize the variance of populations. Research in Population Ecology 41: $229-234$. 